\title{
Implementation of Lesson Study in the Accounting Department for a Financial Management Course
}

\author{
Desi Handayani ${ }^{1}$, Rini Frima ${ }^{2}$ \\ desihandayanisupriyadi@gmail.com ${ }^{1}$ \\ rinifrima1984@gmail.com ${ }^{2}$ \\ Accounting Department, Politeknik Negeri Padang, Kampus Limau Manis Padang ${ }^{1}$, \\ Accounting Department, Politeknik Negeri Padang, Kampus Limau Manis Padang ${ }^{2}$
}

\begin{abstract}
This action research aimed to see how the Lesson Study implemented in Vocational Higher Education. It was designed to be carried out in 2 cycles, while each cycle includes planning (plan), implementation (do) and reflection (see). Lesson Study (LS) was an alternative guide for the lecturer to teach professionally through collaborative and ongoing activities. The principle of collaboration would facilitate lecturers to build effective and efficient learning communities. Financial Management course was chosen as the courses implementing Lesson Study. The research was conducted from August 2019 until October 2019. This course was offered to students of Diploma 4 semester 5 or the third years of the Accounting Department of the Politeknik Negeri Padang. The scope of this course included a study of financial management concepts, calculating and reporting cost calculations and producing cost information which was covering concepts of corporate financial activities and applied the theoretical concepts of financial activity in corporate decision making and analyzing financial statements. Based on the results of research conducted in the first cycle and second cycle there was an increase in the performance of lecturers in carrying out lectures and gave a very good impact. Students were enthusiastic to learn through Lesson Study.
\end{abstract}

Keywords: Lesson Study, Financial Management, Accounting Department.

\section{Introduction}

Educational reform is interpreted as an effort to create programs that focus on improving teaching and learning practices which are intended to overcome the failure of student learning and analyzing their impact on student learning : If a lecturer wants to improve the quality of learning, one of the most obvious ways is to collaborate with other lecturers to design, observe and reflect on the learning process[1][2].

The professional lecturers develop programs that provide opportunities for them to learn "how to learn" and "to learn about teaching" through, for example, Lesson Study (LS). It is a strategy to improve the professionalism of teachers or lecturers. For the last decades, the Lesson Study (LS) has gained rapid popularity outside Japan [3]. LS offers a well-developed set of principles and procedures for supporting teachers' professional learning, focusing on the planning and analysis of research lessons. It has several components that are: determining the focus of studies by identifying improvement aims; planning research lessons by formulating hypotheses and goals; joint research lesson planning; implementing learning and observing learning activities by teaching and observing research lessons; post-research lesson discussion 
by discussing and analyzing the results of observations; and passing on the knowledge gained by and reflections and refinements. These steps or activity can facilitate the improvement of the quality of the learning process and student learning outcomes

Lesson Study (LS) is an alternative guide for the teaching profession through collaborative and ongoing activities [4]. The principle of collaboration will facilitate lecturers to build effective and efficient learning communities, while the sustainable principle will provide opportunities for lecturers to become lifelong learning communities.

LS allows a lecturer to be in class together with other lecturers to observe the learning process carried out by students so that the lecturer can arrange the class and give instructions needed to facilitate the learning process they do [5]. Furthermore, LS is a series of improvement activities that include three interlocked steps in an ongoing cycle, namely PlanDo-See, also known as Planning-Implementation-Reflection [6].

LS is not a momentary project, but it is a continuous activity with quality principles through continuous improvement of students' learning processes and results, based on data. LS activities can encourage the formation of a learning community (learning society) that consistently and systematically improve themselves, both individual and managerial levels. LS provides a real opportunity for lecturers to observe learning (models of lecturer) and student learning processes in the classroom.

These activities give the lecturer the opportunity to examine carefully the learning process and to understand students by observing and discussing learning practices in the classroom. So that lecturers can develop the same understanding or picture of what is meant by effective learning to be able to help students understand what they are learning. This opportunity strengthens the role of lecturers as researchers in the classroom and can be actively involved in the process of learning change and curriculum development. Lecturer collaboration can help reduce isolation between fellow lecturers and develop a shared understanding of how to systematically and consistently improve the learning process and the learning process in college as a whole.

LS seems to integrate many features of effective professional development programs suggested by prior research: it addresses problems of practice; teachers focus strongly on students' learning; preferred instructional practices are modeled and shared; it involves active teacher learning and teacher inquiry; it creates professional learning communities; the setting is appropriate to school-based goals, and learning opportunities are ongoing and sustainable [7].

A good example of a professional development model is Lesson [8]. The core feature of Lesson Study is to observe live classroom lessons by a group of teachers/ lecturers who collect data on teaching and learning and collectively analyze it. Their aim is to improve their lessons in some respect and plan a 'research lesson' together. One of them then teaches the lesson, while the others observe, make notes and collect data on the teaching and learning as it is happening. After the lesson, the teachers meet and analyze the data they have collected together.

A Lesson Study referred to this activity is to find solutions for learning problems in order to increase the quality of learning continuously. The object of learning studies can be in the form of learning training (model lecturers), the training process using a collaborative approach, and a cycle system in learning, which begins with activities:

1. Academic study or academic exploration of syllabi, learning outcomes, indicators, learning objectives, development of teaching materials, LKM (Student Worksheet), multi-media development, multi-method development, innovative learning strategies, development of assessment instruments. 
2. Making RPS (Lecture Quality Plan) based on academic studies.

3. Conduct learning actions based on the observation and discussion, invite colleagues as observers, expert teams as supervisors.

4. Reflect learning actions through sharing, evaluation, and discussion with observers and supervisors.

Implementation in each cycle of Lesson Study is carried out in 3 stages, namely Plan, Do and Reflect. It needed to be monitored and evaluated so that the effectiveness, efficiency, and acquisition of the parties involved will be known.

\section{Methodology}

The research is conduct on the Financial Management course which is offered to the fifth semester of Diploma 4 of the Accounting Department at the Politeknik Negeri Padang. This subject is mandatory for Accounting Department students. The scope of this course includes a study of financial management concepts, calculating and reporting cost calculations and producing cost information. This financial management material covering concepts and theories related to this course. In the course, students can master the theoretical concepts of corporate financial activities and apply the theoretical concepts of financial activity in corporate decision making and analyzing financial statements and be able to solve work problems with the nature and context in accordance with the field of applied expertise based on logical thinking, innovative, and be responsible for the results independently.

The main aims of the research project within the overall project were: (1) to identify the powerful and less powerful components of lecturer discussions as part of an intervention model that can support and foster lecturer learning; (2) to understand the influence of Lesson Study on lecturer learning; and (3) to contribute to theory development about understanding and improving lecturer learning in the context of educational innovation.

This research is action research consisting of 2 cycles. This research is an Action Research which includes the stages of Plan, Do and See. This research is designed to be carried out in cycles, while each cycle includes planning (plan), implementation (do) and reflection (see).

The data analysis method uses a cyclic process approach which is the data analyzed since the learning activity is carried out (from the plan-do-see), developed during the learning process until quality / professional learning is obtained, this data analysis method consists of three streams namely; data reduction, data presentation, conclusion drawing/verification

Data collection methods: observation of model lecturers in lectures, in addition to data collection also uses a questionnaire and in-depth interviews. This research was conducted by Politeknik Negeri Padang. The research began in August-October 2019. The subjects in this study were lecturers with financial management expertise at Accounting Department Politeknik Negeri Padang, totaling 4 people.

Lecturers who participated in the study were accounting lecturer and consisted of lecturers who already had one year's experience of LS at the time the first inventory was administered and lecturer who had no Lesson Study experience yet at that time. 


\section{Finding and Analysis}

\section{Open Lesson implementation.}

First, Plan (Planning). Plan activities are carried out prior to the implementation of learning by the model lecturers. Each Lesson Study team collaborates to study lecture problems and how to solve them. The expected outcome of this collaborative work is the onset of an innovative and ready-to-implement Lecture Quality Plan (RPS = Rencana Pembelajaran Semester / Semester Learning Plan). This planning activity also examines the learning process which includes a syllabus and learning implementation plan that contains at least: learning objectives, teaching materials, teaching methods, learning resources, and assessment of learning outcomes.

The steps for developing the syllabus include:

1) Reviewing Competency Standards.

2) Assessing Basic Competencies.

3) Formulating Competency Achievement Indicators.

4) Formulate Learning Objectives.

5) Identifying and Developing Teaching Materials.

6) Prepare LKM (Student work Sheet).

7) Develop Learning Activities.

8) Determine the Type of Assessment.

9) Determine Time Allocation.

10) Determine Learning Resources.

11) Make the RPS (Lecture Quality Plan)and ready to be implemented

12) Making learning media.

13) Determine the model lecturer, observer, and another lecturer in the same competency to be a part.

Second, Do (implementation). The steps in this stage include;

1). The briefing is guided by the head of the team.

2). The model lecturer presents a short plan (learning plan, objectives, the position of teaching material in the curriculum, estimation of student response possibilities).

3). The team reminds the observer not to intervene in the teaching and learning process.

4). An observer is welcome to choose a strategic place according to the observation plan.

5). Model lecturers carry out the learning process of lectures.

6). The documentation officer, ready to carry out and document all the do's activities.

Third, See (reflection). At the stage of see or reflection, the stages of activities carried out are as follows.

1). The head of the team conveys a reflection mechanism and advises the observer to and speak in an orderly manner or to be a good listener, to speak politely in a constructive manner.

2). The first opportunity is given to the model lecturer to convey her/his reflection.

3). Then the next opportunity for each observer is given the opportunity to convey the results of her/his observations, observer input focused on "student learning activities".

4). Model lecturers are given the opportunity to respond to observer input. 
5). The Lesson Study team summarizes the results of reflection in the minutes of the activity.

6). The head of the team appreciates all of the team for their input and informs them of the next cycle Lesson Study activities

Along with the development of the lecturers learning patterns, the development of their perceptions of LS over time was noted and the influence of lecturing experience was explored.

\section{Procedure}

1) Cycle I: Activities in the first cycle began with planning (plan), where the model lecturer delivered the learning tools, material and plans to be implemented in class. Implementation (do), held on August 22, 2019 August 28, 2019, September 5, 2019, and September 11, 2019. The next activity is a reflection (see) of the learning that has been carried out. This observer delivered her/his findings related to student learning activities. As shown in the following table.

\begin{tabular}{|c|c|c|c|c|c|}
\hline \multicolumn{6}{|c|}{ Cycle 1} \\
\hline Class & Pre-meeting & Meeting 1 & & Meeting 2 & Meeting 3 \\
\hline $\mathrm{A}$ & August 16, 2019 & $\begin{array}{l}\text { August } \\
2019\end{array}$ & 22, & $\begin{array}{l}\text { September } \\
2019\end{array}$ & $\begin{array}{l}\text { September } \\
15,2019\end{array}$ \\
\hline B & & $\begin{array}{l}\text { August } \\
2019\end{array}$ & 28 & $\begin{array}{l}\text { September 11, } \\
2019\end{array}$ & \\
\hline Activity & Plan & implementa & tion & Implementation & Reflection \\
\hline
\end{tabular}

For this first cycle, the team prepared the learning plan for the following material: To explain the concepts in management which consist of Definition of financial management, axioms, and professions in the field of financial management, Types of jobs and tasks at various levels of work level related to financial management such as controller and treasurer, Get to know financial management activities (funding, investment and operating activities), Concept of Time Value Of Money, and The concept of Cost and Benefits in finance

2) Cycle II: The planning activity (plan) begins by submitting a learning plan based on shortcomings and improvements at the first meeting. After the activity is complete, the learning activities (do) are carried out on the date of September 25, 2019, September 26, 2019, and October 3, 2019, and October 2, 2019. The next activity is a reflection (see) of the learning that has been carried out. If there are weaknesses during learning will be used as a reference for improvement and learning that is appropriate will be used as a guide for further learning. 


\begin{tabular}{|c|c|c|c|c|}
\hline Class & Pre-meeting & Meeting 1 & Meeting 2 & Meeting 3 \\
\hline A & \multirow[t]{2}{*}{$\begin{array}{l}\text { September 19, } \\
2019\end{array}$} & $\begin{array}{l}\text { September 26, } \\
2019\end{array}$ & October 3, 2019 & \multirow[t]{2}{*}{$\begin{array}{l}\text { October } \\
2019\end{array}$} \\
\hline $\mathrm{B}$ & & $\begin{array}{l}\text { September 25, } \\
2019\end{array}$ & October 2, 2019 & \\
\hline Activity & Plan & implementation & Implementation & Reflection \\
\hline
\end{tabular}

For the second cycle, the material is: Applying company financial statement analysis: Financial statements as to financial information. Various types of ratios: liquidity, solvency, activity, and profitability. Financial statement analysis techniques. Common size analysis. Index analysis. Analysis of Du-Pont. Ratio analysis. Factors that must be done in comparing the performance of two or more companies.

Based on the results of research conducted in the first cycle and second cycle there is an increase in the performance of lecturers in carrying out lectures. This shows that the application of Lesson Study in the lecturing process has a very good impact. The results of the first cycle show that Lesson Study activities start from the plan, do, and see stages. From the three stages, there was an increase in the quality of lecturer learning. Students were enthusiastic about the learning is given by the lecturers.

Improving the quality of lecturers can be seen from the indicators of lecturers' abilities such as being able to plan to learn, manage classes, choose materials and evaluation tools, choose learning methods and media, utilize information technology, and have a positive attitude towards learning and have a high spirit of collegiality. However, there are some indicators whose scores are still lacking, namely the lack of preparation of learning tools, use of instructional media, and time management. In addition, the participation of lecturers during the implementation of Lesson Study showed a fairly good level of participation such as participating in planning learning, implementing learning, and evaluating learning activities.

The observer also observed that with the Lesson Study the independence of student learning increased. Indeed students need initial instructions from the lecturer before working on. But with these instructions, the students are finally able to discuss and work on the questions given by the lecturer correctly.

Besides that the active, innovative, and creative learning improvement system for students with lectures based on Lesson Study modification. From here the researchers in conducting Lesson Study, at the plan and see stages both in cycle I and II shared with the model lecturer that the modified Lesson Study in lectures at Accounting Department Politeknik Negeri Padang can be done with Collaborative based learning and connecting each material with an updated material from Real case in accordance with lecture material.

Of all the stages of Lesson Study conducted in cycle I and cycle II, Lesson Study is an effective way to improve the quality of learning conducted by lecturers and student learning activities. In addition, if a Lesson Study is well designed, this is an activity that will make lecturers become professional and innovative. Innovative here in the selection of learning methods that are consistent with the material and innovative in carrying out scientific activities that support the quality of lecturer performance.

The benefits of Lesson Study activities in this study are that lecturers can increase knowledge again and can study what kind of learning is suitable for students. Learning here is 
the selection of the right method. It also can enhance learning that is beneficial for students. From here it is hoped that lecturers can think of long-term goals after the Lesson Study ends that will be achieved by students. However, in this study researchers not only looked at the quality of learning but also on the performance of lecturers.

At the managerial level, with the direct involvement of the head of the department as LS participants, of course, the head of the department will obtain a number of valuable inputs for the interests of developing education management in the study program as a whole. If all this time the leader much preoccupied with matters outside education, with his direct involvement in the LS, he will be able to better understand what is actually experienced by lecturers and students in the learning process, so hopefully the head of the department can be even more focused to realize himself as an educational leader in the study program.

The implementation of Lesson Study in Financial Management on accounting has contributed to improving the quality of learning and improving the quality of lecturers, including:

1. Improved Learning Preparation.

Before lecturing, all of the financial management lecturers had been required to prepare RPS (lesson Plan). It was a full sacrifice moment because of not all teams willing to change their plan of study. It needed willingness and spaciousness, in order to reach the same vision. With the expansion of Lesson Study programs to strengthen study programs, its encouraging lecturers before teaching to prepare RPSs with their tools, including preparing LKM (Student Activity Sheets), developing materials, innovative learning strategies, post-tests, psychomotor assessments, assessment processes, and multi-media learning. By Lesson Study, lecturers must develop their learning tools in the workshops for the preparation of teaching plans and teaching materials. Teaching plan workshops and teaching materials are conducted by each Lesson Study team lecturer. The results of the teaching plan workshop and teaching material are reviewed by other lecturers (observers) before the open lesson. In other words, model lecturers prepared well their lesson.

2. Grow Collaborative Work. Lesson-based lecturer coaching encourages lecturers in lecturing activities to be carried out collaboratively with the other team. This collaboration process has an impact on improving the learning process that emphasizes the higher cognitive aspects (HOT / Higher Order Thinking). It also encourages model lecturers to use innovative learning strategies in accordance with the character of each material for better high-level academic aspects such as a) sharpness of analytical and evaluation power, b) development of student creativity and independence, and c) development of affective and academic skill aspects for students.

3. Contributions to collegiality. The observer lecturer finds that the class is the authority of the lecturer, everything that happens in the classroom is the authority of the lecturer concerned so that other lecturers do not need to know what is happening in their class, other lecturers also seem not to care about the learning done by their colleagues. If there are problems with students, the root of the problem is difficult to 
detect. Lesson Study is able to provide solutions and provide input to lecturers with the view as above, which then collegiality impacts other lecturers. In addition, with the existence of Lesson Study activities for one semester, lecturers of one family of experts will meet at a minimum eight times to discuss the learning of the course, give each other corrections, give each other input, and in turn will enhance high-level academic abilities.

4. Student Learning Readiness. Some students have difficulty concentrating. Based on these findings, it concludes that those students who are present in the classroom may not necessarily have their thoughts following the learning process. Experienced from this Lesson Study, finally the need for controlling of student activities while attending lectures. In addition, students' learning readiness is marked by material readiness, modules, assignments given by previous lecturers. From observations through observer lecturers, it was found that some students were actually not ready to take part in learning because of the incomplete and minimum facilities of their learning. Based on this finding, some lecturers made a rule of learning readiness of at least students who could take lectures.

5. Improving the Learning Process Based on Reflection Results. The results of observations will be conveyed to the model lecturers and the team at the time of reflection, as a positive finding, authentic input to be followed up by all team lecturers including non-model lecturers. This reflection will provide direct experience to model lecturers and teams in improving planning and learning processes based on the results of reflection.

6. Development of Learning Media. So far, the media used are only limited to visual media (powerpoint), but through Lesson Study based learning in addition to visual media other media.

7. Development of assessment tools. An assessment conducted in the learning process has not touched on all domains of assessment, generally limited to cognitive, but through the development of Lesson Study-based learning in addition to cognitive assessment also developed an assessment of the affective and psychomotor domains in the learning process.

\section{Conclusion}

It can be noted that Lesson Study should be an analysis and investigating of teaching and learning. The instruction of the lesson plan is prepared well before implemented in class. Lesson study is a manageable task and all team takes responsibility. Teams can schedule meetings as needed.

College lesson study is an opportunity to work with colleagues on substantive issues and problems related to teaching and learning. Although instructors (lecturer model) design only a single lesson, but what they learn from the experience can be applied to other classes and contexts. 


\section{References}

[1] A. Takahashi, "Mathematics Teacher Education and Development The Role of the Knowledgeable Other in Lesson Study: Examining the Final Comments of Experienced Lesson Study Practitioners."

[2] S. Dotger, "Exploring and developing graduate teaching assistants' pedagogies via lesson study," Teach. High. Educ., vol. 16, no. 2, pp. 157-169, Apr. 2011.

[3] P. Dudley, H. Xu, J. D. Vermunt, and J. Lang, "Empirical evidence of the impact of lesson study on students' achievement, teachers' professional learning and on institutional and system evolution," Eur. J. Educ., vol. 54, no. 2, pp. 202-217, Jun. 2019.

[4] S. Hendayana and M. A. Karim, "Studi Peran IMSTEP dalam Penguatan Program Pendidikan Guru MIPA di Indonesia," 2007.

[5] C. Fernandez, "Learning from Japanese approaches to professional development: The case of lesson study," J. Teach. Educ., vol. 53, no. 5, pp. 393-405, Nov. 2002.

[6] C. Lewis, R. Perry, and A. Murata, "How Should Research Contribute to Instructional Improvement? The Case of Lesson Study," Educ. Res., vol. 35, no. 3, pp. 3-14, 2006.

[7] V. Donche and P. Van Petegem, "The development of learning patterns of student teachers: A cross-sectional and longitudinal study," High. Educ., vol. 57, no. 4, pp. 463-475, 2009.

[8] J. M. Lewis, "Teacher Learning in Lesson Study Let us know how access to this document benefits you .," vol. 10, no. 3, 2013. 